\title{
A Preliminary comparative study on the Antimicrobial properties of Cassia alata, Jatropha curcas, Aloe barbadensis and Alluim sativum
}

\author{
${ }^{1}$ Nwankwo, J. I. and ${ }^{2}$ Nwankwo, B. N. \\ ${ }^{I}$ Department of Applied Microbiology and Brewing, Faculty of Applied Natural Sciences, Enugu State \\ University of Science and Technology Agbani, Enugu State, Nigeria. P.M.B 01660 Independence Layout \\ Enugu. \\ ${ }^{2}$ Nursing Services Division (Burns and Plastic Unit), National Orthopaedic Hospital Enugu, Nigeria.
}

\begin{abstract}
Anti-microbial properties of ethanol and equeous extracts of locally available plants: Cassia alata; Jatropha curcas, Allium sativum and Aloe barbadensis on Staphylococcus aureus, Candida albicans, Streptococcus pyrogenes and Esherichia coli were studied. Paper disc diffusion method was used to determine the inhibitory effects of both the leaf and seed extracts of test plants on the micro-organisms. The plant extract produced inhibitory zones ranging from 0 to $4.0 \mathrm{~mm}$ against test organisms. The water extracts of the test plant proved effective more than the ethanol extracts, water extracts of Allium sativum were effective only on Candida albicans and Esherichia coli while the extracts of Aloe vera were only effective on E.coli and Streptococcus pyrogenes. Extracts of Jatropha curcas were effective against all the test organisms except Candida albicans while extracts of Cassia alata were effective against all except Streptococcus pyrogenes and Candida albicans.

Keywords: Anti-microbial, Cassia alata, Jatropha curcas, Allium sativum and Aloe barbadensis.
\end{abstract}

\section{Introduction}

In Nigeria the climate favours a great array of plant species, many of which have varied medical and anti-microbial potentials [1, 2, 3 and 4]. Earlier studies have shown that plants that have medicinal and antimicrobial values have either alkaloid; steroids, tannins, glycosides and various oils and they tend to be sites for the active medicinal ingredient of such plants $[5,6,7$ and 8]. Three compounds may be found in a particular part of the plant or all over its body and they are often localized in glands [9, 10 and 11]. Plants that have medicinal and anti-microbial properties in Nigeria have been identified and documented [12 and 13]. Some of the active ingredient of the extract of some of these plants have been isolated, tested and documented [14 and 15]. The development and spread of resistance to the existing antibiotics by micro-organism cells has increased efforts in the development of new antibiotics for the treatment of microbial infection and disease $[16,17$ and 18]. Although a number of plants with anti-microbial activities have been identified, a great number still remain unidentified [19, 20 and 22].

Recently, great expectations have been aroused by natural substances, especially biologically active compounds produced by higher plants due to their own multi directional, biological activity and few side effects [23, 24 and 24]. In addition to having anti-mycotic properties many substances of natural origin stimulate natural and potential immunity. A substrate problem is the appearance of drug resistance strains. However, this phenomenon is less common in the case of media derived from plants than from those of chemotherapeutical and anti-mycotic antibiotics. Historically, many bioactive substances have been natural products. Therefore, it is logical that the search for new prototype anti-fungal products should also include natural products. The major advantage of this approach over chemical synthesis or modification of existing agents is the likelihood of similar intoxication, cross-resistance or even mechanism of action. Over the past several decades the search for antifungal has been limited primarily to micro-organisms particularly Actinomycetes and some fungi [25 and 26]. The search for new anti-fungal agents or modifications of those already known is not easy and producing on effective anti-mycotic drug is even more difficult than finding on antibacterial preparation. Higher plants are a valuable source of many biologically active substances.

The purpose of this research was to evaluate the anti- microbial activities of Jatropha curcas, Allium sativum, Aloe vera and Cassia alata on Staphylococcus aureus, Escherichia coli, Streptococcus pyrogenes and Candida albicans.

\section{Materials And Methods}

Collection of Samples: The leaves and seeds of Jatropha curcas, Aloe vera, Cassia alata and Allium sativum used were bought from Ogbete Main Market, Enugu, they were dried for five days. The back of the garlic was removed and air dried. 
Extraction of Active Ingredients: The extraction was done using the method described by Asuzu (1986) [3]. $15 \mathrm{~g}$ of the ground plant were soaked in $50 \mathrm{ml}$ of distilled water for each sample in separate conical flasks for 6 days. The extracts were filtered using Whatman No 1 filter paper after which the filtrates were stored in the refrigerator until required.

Ethanol Extraction: The ethanol extraction of the active ingredient of the plant parts were carried out using the method of Harbone (1973) [15]. In this method 1 gram of each of the ground plant part was extracted using $10 \mathrm{ml}$ of ethanol. The extraction of each of the plants lasted for 3 days and the active ingredients were collected and stored in the refrigerator until required.

Media Used: Media used were Nutrient Agar (Lab. m) and Sabourand Dextrose Agar (Lab. m). The media were prepared according to the manufacturer's instructions.

Test Organisms: The bacteria and fungi species used in this study were kindly donated by Atlas and ASO laboratories 118 Agbani Road, Enugu. The bacteria were cultured and maintained as described by Cruickshank et al (1980) [8]. The isolates were identified using biochemical methods as described by [19 and 20]. The fungus by the wet preparation method described by Fawole and Oso (1996) [13]. The bacteria species are co-agulase positive Staphylococcus aureus, Streptococcus pyrogenes and Escherichia coli, while the species is Candida albicans.

Ant-microbial Test: The method adopted was the agar disk diffusion method. In this method the paper disc diffusion tests as described by Opera and Anasa (1993) [21]. Sterile paper discs were soaked in the different plant extracts for $24 \mathrm{~h}$. The surface of the well-labeled agar was inoculated with the various bacterial and fungi suspensions. The paper discs containing different extracts were placed at different areas on the surface of each plate. The plates were incubated at $37^{\circ} \mathrm{c}$ for $24 \mathrm{~h}$. Anti-microbial activity of each extract against the test bacteria was indicated by growth -free zone of inhibition near the respective discs. This save method used to test for anti-fungal activity but the fungus was grown on sabourand dextrose agar plates at $28^{\circ} \mathrm{C}$ for $48 \mathrm{~h}$ before the paper disc dipped in the plants extracts were planted on the plates. A disc soaked in the extracting solvent for 24 $\mathrm{h}$ was used as the control. This procedure was also used for the plant soaked in ethanol.

\section{Results}

The aqueous extract of the plants showed various levels of anti-microbial activity when tested by disc diffusion method, where as the ethanol extract showed no anti-microbial activity when tested by the paper disc diffusion method.

Generally, all four plants: Cassia alata and Jatropha curcas showed high inhibitory zones of between 1.0 to $2.5 \mathrm{~m}$ against Staphylococcus aureus, while Aloe vera and Allium sativum had no anti-microbial activity against the same organism.

However, all four plants had anti-microbial effect on Escherichia coli. Both Cassia alata and Jatropha curcas had more effect than Allium sativum and Aloe vera on E.coli. Only Jatropha curcas and Aloe vera had inhibition zones of between 1.8 to $2.0 \mathrm{~mm}$ while Aloe vera had $2.0 \mathrm{~mm}$. It also shows that Cassia alata and Allium sativum had no anti-microbial effect on the other organism.

Furthermore, Allium sativum remarkably high anti-microbial effect on Candida albicans, with inhibitory zones of between 1.2 to $3.4 \mathrm{~mm}$, while the extracts of Cassia alata, Jatropha curcas, and Aloe vera had no antimicrobial effect against the same organisms. Similarly the ethanol extracts of the test plants showed nothing.

TABLE 1: Inhibitory properties of plant extract towards bacteria and fungi (incubation zone diameter in mm) (aqueous extraction result).

\begin{tabular}{|l|l|l|l|l|}
\hline Organism & Cassia & Jatropha & Allium & $\begin{array}{l}\text { Aloe } \\
\text { Vera }\end{array}$ \\
\hline Staphylococcus & 2.5 & Curcas & - & - \\
Aureus & 1.8 & 1.2 & - & - \\
& - & 1.1 & - & - \\
\hline Escherischia & - & 1.0 & - & - \\
Coli & 1.2 & - & - & - \\
& 2.6 & 2.0 & - & - \\
& 2.3 & 1.0 & 0.1 & 1.8 \\
\hline Streptococcus & - & 0.7 & - & - \\
pyogenes & - & - & - & 2.0 \\
& - & 1.8 & - & - \\
& - & 1.2 & - & - \\
Candida & - & 2.0 & - & - \\
Albacians & - & - & 1.2 & - \\
\end{tabular}


A Preliminary comparative study on the Antimicrobial properties of Cassia alata, Jatropha curcas,

\begin{tabular}{|l|l|l|l|l|}
\hline & - & - & 3.4 & - \\
\hline
\end{tabular}

\section{Discussion}

Thomas Jefferson wrote that " the greatest service which can be rendered any country is to add a useful plant to this culture" Plants have forever been a catalyst for our healing. In order to halt the trend of increased emerging and resistant infection diseases, it will require a multi-pronged approach that included the development of new drugs. Using plant as the inspiration for new drugs provides an infusion of novel compounds or substances for healing diseases. Evaluating plants from the traditional African system of medicine provide wonderful idea used in the treatment of disease (Boakye et al., 1977) [5].

The results of this study showed that the leaf and seed extracts of the test plants : Cassia alata, Jatropha curcas, Allium sativum and Aloe vera have good inhibitory effects against Staphylococcus aureus, Escherichia coli, Streptococcus pyrogenes and Candida albicans.

The water extract of the plant parts showed more inhibitory effects than the ethanol extracts which did not have any inhibitory effect at all. This tends to show that the active ingredients of the plants parts were better extracted with water than ethanol. Also that all the plants that had their leaves extracted tend to have effect more on bacteria than on fungi (Asuzu, 1986) [3]. The seed of Allium sativum also tends to show a clear effect on fungi (Candida albicans). Even though Aloe vera showed a minimal effect on Escherichia coli and Streptococcus pyrogenes that it does not make it to be graded with both Cassia alata and Jatropha curcas in the same class as having a higher effect on bacteria. Akunyili et al., (1991) [1] observed a similar result when they worked with stem bark of Kigelia pinnata. The failure of ethanol to extract maximally the active ingredients in those plants parts may be responsible for the no inhibitory effects the ethanol extracts had both on the bacterial and fungi organisms; whereas the water extracts of the same plants parts had good inhibitory effects against the same organisms. In case of leaves of Cassia alata and Jatropha curcas and the seed of Garlic, here it has shown more inhibitory effects against the bacterial species than the fungus Candida albicans (Harbone, 1973) [15]. The extracts of Garlic showed wider zones of incubation against Candida albicans than other plant extracts.

Since the extracts of the plant produced good inhibitory zones against the test organisms, it is expected that they could be used to treat infection and diseases caused by these organisms and if the active ingredients of extracts are isolated and possibly crystallized, therapeutic antibiotics could be produced from them.

\section{Conclusion}

In conclusion, the plants presented here showed a very promising activity in the area of anti-microbial agents, warranting further investigations. The need for economic, rapid, sensitive and accurate bioassays for fungi toxic compounds is apparent from the problem caused by them. Recent development with anti-fungal and bacterial; drugs have pointed once more to the plant kingdom. Large numbers of plants continue to be used in traditional medicine for anti-fungal and bacteria diseases, and such plants need to be tested for their efficacy.

\section{References}

[1]. Akunyilli, A.N., Houghton, D.J., and Roman. (1991). Anti-bacterial activities of the stem bark of Kigelia pinneta. Journal of Ethnopharmacology, 2: 173 -177.

[2]. Arunkumar S, Muthuselvam M. Analysis of Phytochemical Constituents and Antimicrobial Activities of Aloe vera L. against clinical pathogens. World Journal of Agricultural Sciences 2009; 5(5): 572-576.

[3]. Asuzu, I.U. (1986). Pharmacological evaluation of folklore of sphenostila slenocorpa. Ethanophanacol Journal, $16: 236$ - 267.

[4]. Bennet, J., (1991). Anti -fungal agents. In the pharmacological basis of therapeutics, volume II. Gillmann, A.G., Roll, T.W., Nies, A.S., and Taylor, P . (1 ${ }^{\text {st }}$ Edition). New York : Pergamon Press Pp. 1165-1198.

[5]. Boakye - Yiadom, K., Fiagbe, N., Ayim S. (1977). Anti-microbial properties of some West African medicinal plants iv. Antimicrobial activity of xylopic acid and other constituents of the fruits of xylopia-aethiopica (Annonaceae). Lloydia, 46:543-545.

[6]. Brayshaw, O.P. (1999). Methicilin - resistant. Staphylococcus: evaluation of detection techniques on laboratory passaged organisms. British Journal of Biomedical Sciences, 56: 170-176.

[7]. Calvary, E.M., Roach, J.H.G., (1994). Supercritice fluid chromatography of garlic (Allium setivum) extract with mass spectromers identification for allicin. Journal of chromatogram Science, 32 ; 93-96.

[8]. Cruickshark, K., Daguid, J.P., Marnion, B.P., and Swain, R.H. and Swain, R.H. (1980). Medical microbiology (12 $2^{\text {th }}$ Edition London Churchill-living stone and $\mathrm{Pp}:$ : 180-188.

[9]. Dismukes, W.E. (1991). The present status of anti-fungal treatment, with particular reference to systemic infections. A review: current medical red-cross opinion supply, 12:49-52.

[10]. Ebona, R.U., Essien, A.I and Ekpa, O.D. (1995). Nutritional and potentially medicinal values of the leaves of lasianthera Africana (Beavv). Global Journal Pure and Applied Science, Pp: $1-8$.

[11]. Eshun K, He Q. Aloe vera, a valuable ingredient for the food, pharmaceutical and cosmetic industries. Herbs for Health magazine 2004; 44(2): 91-96.

[12]. Esimone C., Nworu C., Ekong U. and Okereke B. Evaluation of the antiseptic properties of Cassia alata-based herbal soap. The Internet Journal of Alternative Medicine. 2007 Volume 6 Number 1.

[13]. Fawole, N.V. and Oso, E.A. (1986). Laboratory manual of microbiology spectrum books limited. Ibadan, Nigeria. Pp: 18-22.

[14]. Gutkind, G.O., Martino, V., Grana, N., Coussio, J.O., and Detorres, R.A. (1981). Screening of South American plants for biological activities, Antibacterial and anti-fungal activity. Fitoterapia Journal, 52;213-218.

[15]. Harborne, N.V., (1973). Phyto chemical method. A guide to modern techniques of plant analysis. London press, Pp:425. 
[16]. Hilli, p., Evar, C.S. and Veness, R.G. (1977). Anti-microbial action of essential oil. The effect of dimethyl sulphoxide on the activity of sinamon oil. Applied Microbial Letters, 21:269-275.

[17]. Iwu, M. Igboko, A.V. (1982). Flavonoids of Garcinia Kola Seeds. National product Journal, 45: 650-651.

[18]. Khan, M.R., Ndaalio, G., Nkunga, M.H.H., and Sawwney, A.N., (1985). Studies on African medical plants for anti-bacterial activity. African Journal of Medical Sciences. 15: 65-69.

[19]. Ogbonna Ann O., Ikeyi Adachukwu P., Nweke Okechukwu E. and Ugwu Okechukwu P.C. (2013). Studies on the effect of aqueous extract of Dennetia tripetala (Mmimi pepper fruit) seeds on Escherichia coli. International Journal of Research and Reviews in Pharmacy and Applied Science, 3(6): 858-866.

[20]. Ogbonna Ann O., Ikeyi Adachukwu P., Okafor Cecilia Ifunanya and Ugwu Okechukwu P.C. (2013). Isolation of Bacteria that are Associated with the Fermented Product of Mesquite Seed Locust Beans (Prosopis africana) Okpeye. International Journal of Research and Reviews in Pharmacy and Applied Sciences, 3(6): 838-847.

[21]. Opera, A.A and Ansa, M.A. (1993). The anti-bacterial activity of Tea and Coffee on selected organism. Medical Laboratory Science Journal, 3:15-48.

[22]. Paxton, J.O. (1991). Asays for antifungal activity : In methods in plant biochemistry. Academic press London . Pp 33-46.

[23]. Tewari, J.P and Shukla, I.K. (1982). Inhibition of infectivity for 2 strians of watermelon mosaic virus by latex of some angiosperms. Geobios . jodhpur India, 93: 124-126.

[24]. Thiruppathi S, Ramasubramanian V, Sivakumar T, Thirumalai Arasu V. Antimicrobial activity of Aloe vera (L.) Burm. f. against pathogenic microorganisms. J. Bio sci. Res. 2010; 1(4): 251-258.

[25]. Watt, J.M and Breyer-Brandwijk, M.G. (1962). The medical and poisonous plants of southern and eastern African, $2^{\text {nd }}$ edition. Levingstone, limited, Edinburgh and London. Pp:42-92.

[26]. Zacchino, S., Rodrigues, G., Santecchia, C., Pezzanati, G., Gnannini, F., and Furiz, R. (1998). in vitro studies on mode of action of anti-fungal 8-0-4- nolegans occurring in certain species of virola and related general of myristicaci. Journal of Ethnopharmacology, $6235-41$. 